\title{
Cysts of the Oral Mucosa in Newborns : A Clinical Observation
}

\author{
Kunio Ikemura', Yasuaki Kakinoki', Kazukata Nishio ${ }^{2}$ and Yoshinori Suenaga ${ }^{2}$ \\ 'Department of Dentistry and Oral Surgery, Hospital, University of Occupational and \\ Environmental Health, Japan. Kitakyushu 807, Japan \\ 2Department of Dermatology, School of Medicine, University of Occupational and \\ Environmental Health, Japan. Kitakyushu 807, Japan
}

\begin{abstract}
Nodules or cysts of the oral mucosa occurred with an incidence of 88.7 per cent in 541 Japanese newborn infants. No infant was over 8 days old. This incidence is higher than that reported in Caucasian and Negro newborns. It may be suggested that the frequency of visible nodules have a close relation to growth and development in the fetal life, because the cysts seen in newborns can be recognized histologically in most fetuses, as demonstrated in other papers. Although a variety of terminology for these nodules have been used, these oral cysts can be classified as follows: gingival cyst in the newborn (dental lamina cyst) and median palatal mucosal cyst (Epstein's pearl).
\end{abstract}

Key words: cyst, oral mucosa, newborn.

(Received 15 February 1983)

\section{Introduction}

Although small nodules or cysts of the oral mucosa are a very common finding in newborn infants, they are not always a well-known condition to general clinicians and there are only a few reports (Monteleone \& McLellan, 1964; Fromm, 1967; Cataldo \& Berkman, 1968) on clinical observations of a large number of newborns. This may be due to the fact that clinicians have few chances to inspect the oral mucosa of the newborn or they disappear spontaneously (Cataldo \& Berkman, 1968; Higuchi et al., 1981).

It is the purpose of this paper to describe the results of clinical observations in Japanese newborn infants and to comment on the terminology for these nodules.

\section{Materials}

A total of 541 infants were examined. No infant was over 8 days old. The days after birth, sex and body weight were recorded. Subsequent to an oral examination, the location and the number of mucosal nodules were recorded. They were white or yellowishwhite in colour and varied in size from less than $2 \mathrm{~mm}$ to $5 \mathrm{~mm}$ (Fig. 1). 


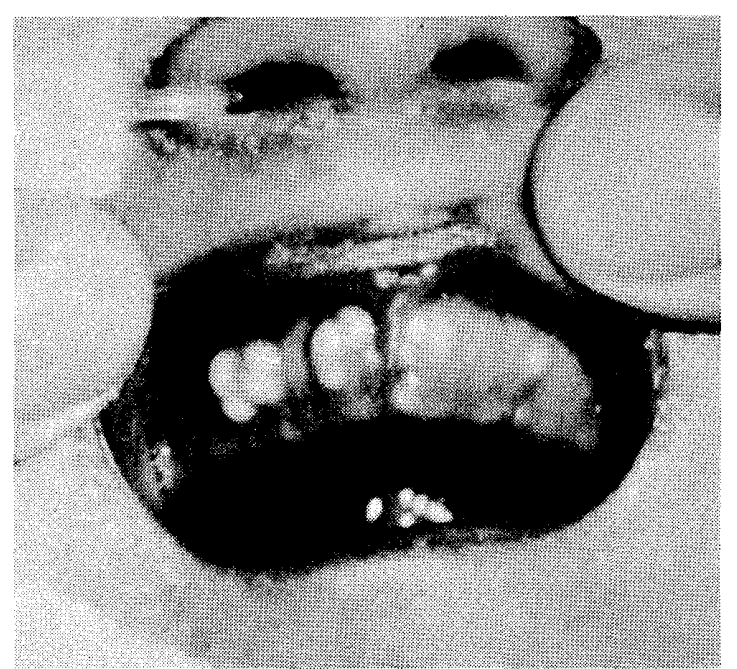

Fig. 1. Nodules of the maxillary gingiva (twenty-day-old infant).

Table 1. Incidence of nodules by sex

\begin{tabular}{lccc}
\hline \multicolumn{1}{c}{ Sex } & $\begin{array}{c}\text { No. of } \\
\text { cases }\end{array}$ & $\begin{array}{c}\text { Nodules } \\
\text { present }\end{array}$ & $\begin{array}{c}\text { Frequency } \\
(\%)\end{array}$ \\
\hline Male & 261 & 236 & 90.4 \\
Female & 280 & 244 & 87.1 \\
Totál & 541 & 480 & 88.7 \\
\hline
\end{tabular}

\section{Results}

Of 541 newborn infants, nodules occurred with an incidence of 88.9 per cent. Male infants exhibited a higher incidence than female infants (Table 1). The incidence in newborns weighing between 2.0 and $3.9 \mathrm{~kg}$ was approximately 90 per cent (Table 2). When comparing this percentage with the incidence in newborns over $4.0 \mathrm{~kg}$ body weight, a statistically significant difference $(P<5 \%)$ was noted. As for the incidence by days after birth (Table 3), the group examined earlier had a higher frequency than the group examined later, without statistical significance.

The nodules were most often seen along the median raphe of the hard palate (Table 4). No nodules were found in the region of the soft palate. In the maxillary gingiva, nodules were frequently seen on the buccal side while the mandibular gingiva demonstrated a lingual predominance. The average number of nodules was 3.3 in 480 newborns with nodules present (Table 5) and the highest number recorded was twentyfour. The number of nodules had no relation to the age of the infant at examination. 
Table 2. Incidence by body weight

\begin{tabular}{cccc}
$\begin{array}{c}\text { Weight } \\
(\mathrm{kg})\end{array}$ & $\begin{array}{c}\text { No of } \\
\text { cases }\end{array}$ & $\begin{array}{c}\text { Nodules } \\
\text { present }\end{array}$ & $\begin{array}{c}\text { Frequency } \\
(\%)\end{array}$ \\
\hline $2.0-2.4$ & 28 & 25 & 89.3 \\
$2.5-2.9$ & 139 & 125 & 89.9 \\
$3.0-3.4$ & 253 & 224 & 88.5 \\
$3.5-3.9$ & 107 & 96 & 89.7 \\
$4.0 \leqq$ & 14 & 10 & 71.4 \\
Total & 541 & 480 & 88.7 \\
\hline
\end{tabular}

Table 3. Incidence by days after birth

\begin{tabular}{cccc}
\hline $\begin{array}{c}\text { Days after } \\
\text { birth }\end{array}$ & $\begin{array}{c}\text { No. of } \\
\text { cases }\end{array}$ & $\begin{array}{c}\text { Nodules } \\
\text { present }\end{array}$ & $\begin{array}{c}\text { Frequency } \\
(\%)\end{array}$ \\
\hline 0 & 39 & 38 & 97.4 \\
1 & 85 & 82 & 96.5 \\
2 & 85 & 75 & 88.2 \\
3 & 98 & 87 & 88.8 \\
4 & 91 & 75 & 82.4 \\
5 & 55 & 49 & 89.1 \\
6 & 56 & 46 & 82.1 \\
7 & 32 & 28 & 87.5 \\
Total & 541 & 480 & 88.7 \\
\hline
\end{tabular}

Table 4. Incidence by site

\begin{tabular}{lcc}
\hline \multicolumn{1}{c}{ Site } & $\begin{array}{c}\text { Nodules } \\
\text { present }\end{array}$ & $\begin{array}{c}\text { Frequency } \\
(\%)\end{array}$ \\
\hline Median palatal mucosa & 369 & 68.2 \\
Maxillary gingiva & 293 & 54.1 \\
Mandibular gingiva & 84 & 15.5 \\
\hline
\end{tabular}

Table 5. Incidence by number of nodules

\begin{tabular}{crc}
$\begin{array}{c}\text { No. of } \\
\text { nodules }\end{array}$ & $\begin{array}{c}\text { No. of } \\
\text { cases }\end{array}$ & $\begin{array}{c}\text { Frequency } \\
(\%)\end{array}$ \\
\hline 0 & 61 & 11.3 \\
1 & 131 & 24.2 \\
2 & 96 & 17.7 \\
3 & 83 & 15.3 \\
4 & 65 & 12.0 \\
5 & 43 & 7.9 \\
6 & 29 & 5.4 \\
7 & 9 & 1.7 \\
8 & 5 & 0.9 \\
9 & 4 & 0.7 \\
10 & 15 & 2.8 \\
Total & 541 & \\
\hline
\end{tabular}




\section{Discussion}

In 1967 Fromm reported that there was a difference in the incidence of mucosal inclusion cysts between Caucasian and Negro newborn infants. He examined 1367 newborn infants, less than 48 hours old, and stated that inclusion cysts of the oral mucosa were found less frequently in Negro newborn infants than in Caucasian counterparts with percentages of 63.0 and 76.8 per cent respectively. Our observation showed that the incidence of nodules in Japanese newborn infants was 88.7 per cent and that the incidence in 209 newborns less than 48 hours old was 93.3 per cent (Table 3). Monteleone \& McLellan (1964) observed newborn infants within the first 24 hours after birth and reported that Epstein's pearl formation occurred in 79 per cent of 293 Negro infants and 85 per cent of 100 Caucasian infants. When our cases were confined to the same condition, the incidence was 91.4 per cent of 124 cases. Therefore, present studies indicate that the nodules are seen more frequently in the Japanese newborn infants than in the Caucasian and Negro newborn infants.

In Fromm's report (1967) no correlation existed between the weight of the infant and the incidence of inclusion cysts. However, the results obtained here show a statistical correlation between body weight and the incidence of nodules, bordering $4.0 \mathrm{~kg}$ in weight (Table 2). In addition, the infants who were examined soon after birth had a higher frequency than other groups (Table 3) and in most cases the nodules disappeared spontaneously within a few months (Cataldo \& Berkman, 1968; Higuchi et al., 1981). Furthermore, the histological findings of cysts seen in newborn infants can be recognized in most fetuses (Scott, 1955; Burke et al., 1966; Moreillon \& Schroeder, 1982), and Moreillon \& Schroeder (1982) state that the high number of fetal microkeratocysts gradually decreases in late fetal life and early postnatal life. Therefore, it may be concluded that the frequency of visible nodules have a close relation to growth and development in the fetal life or in the early postnatal life.

The most common location was the median palatal mucosa (Table 4). In comparison to the results reported by Cataldo \& Berkman (1968), our examination showed the higher incidence of nodules in the mandibular gingiva. As to the number of nodules (Table 5), description sufficient for comparison could not be obtained from other reports.

The small nodules of the oral mucosa in infants have been described by different terminology (Monteleone \& McLellan, 1964; Fromm, 1967). Nomenclatures come from the name of the reporter (Epstein's pearl, Bohn's nodule), histological findings (epithelial cysts, inclusion-cysts, microkeratocysts. mucous-gland cysts), and confused origin (epithelial rests, epithelial buds of the enamel organs, epithelial debris of the tooth follicle, abortive enamel organs, epithelial remnants of the dental follicle). The investigations of the fetus (Scott, 1955; Burke et al., 1966; Moreillon \& Schroeder, 1982) demonstrate that the nodules arise from the dental lamina and the fusion of the palatal shelves. Epstein's 


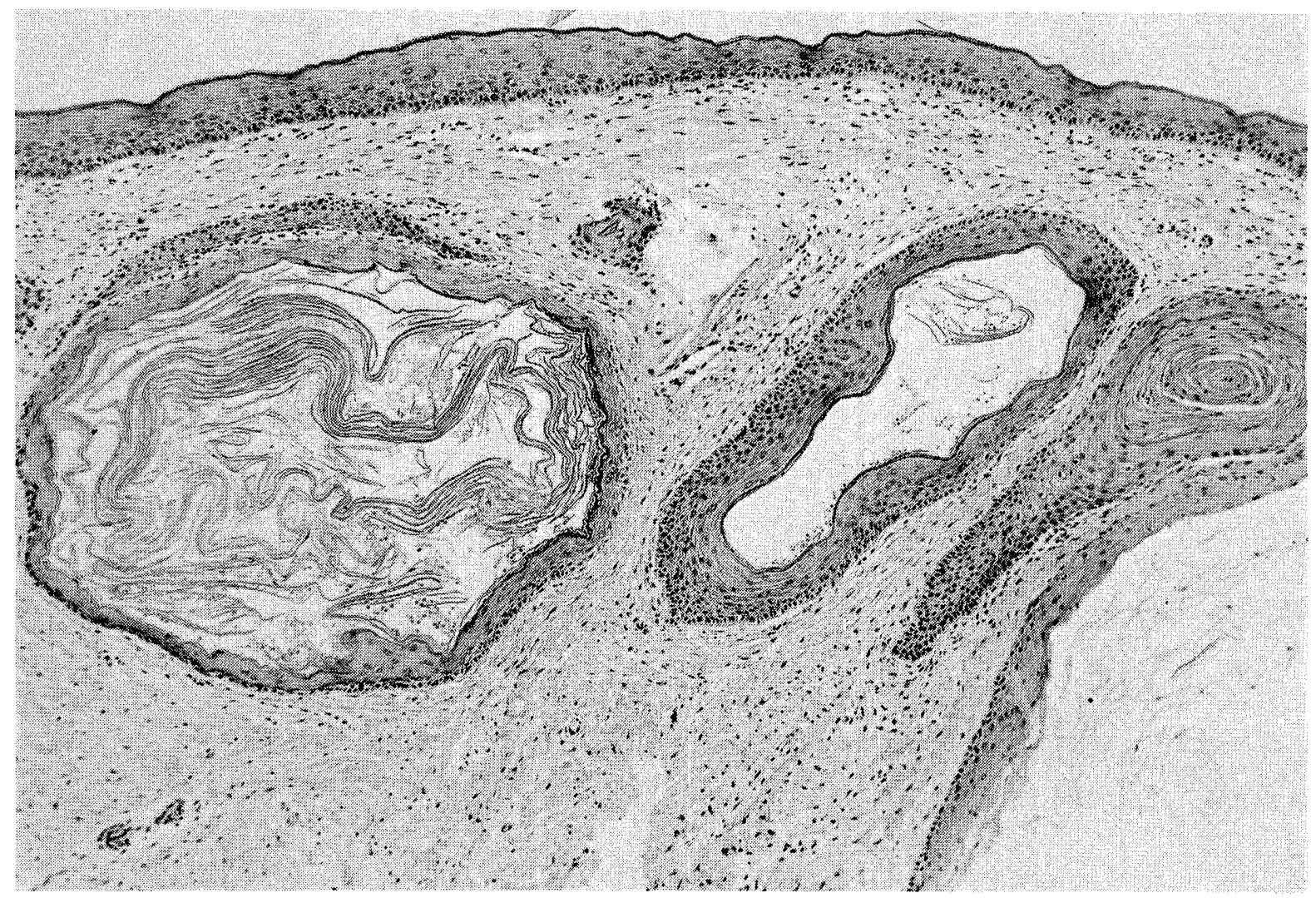

Fig. 2. The cysts are lined with stratified squamous epithelium. The contents of these cysts are keratin. (Hematoxylin and eosin stain. Magnification, $\times 87$.)

pearl indicates the nodules along the median palatine raphe and Bohn's nodule means the mucous-gland cyst rising from the remnants of the mucous gland (Fromm, 1967), possibly outside the midpalatine region. The nodules of both the median palatal mucosa and the gingiva show pathologically the cyst (Fig. 2). These cysts of the oral mucosa in newborns may be classified as follows : gingival cyst in the newborn (dental lamina cyst) and median palatal mucosal cyst (Epstein's pearl). The former is used to avoid the confusion with gingival cyst in the adult and the latter to differentiate from fissural cyst occurring in the maxillary bone.

\section{Acknowledgement}

We are deeply grateful to all staffs of Angel Hospital in Kitakyushu City and of the Department of Obstetrics, University of Occupational and Environmental Health, for their cooperation in examining the oral cavities of newborn infants. We also wish to thank Miss K. Yasutake for typing the manuscript. 


\section{References}

Burke, G. W., Jr., Feagans, W. M., Elzay, R. R. et al. (1966): Some aspects of the origin and fate of midpalatal cysts in human fetuses. J. Dent. Res., 45: 159-164.

Cataldo, E. \& Berkman, M. D. (1968): Cysts of the oral mucosa in newborns. Amer. J. Dis. Child., 116: 44-48.

Fromm, A. (1967): Epstein's pearls, Bohn's nodules and inclusion cysts of the oral cavity. J. Dent. Child., 34: 275-287.

Higuchi, T., Yamamoto, M., Ogino, A. et al. (1981): The occurrence and frequency of oral microcysts (so-called Epstein's pearl) in infants. Hifurinsho., 23: 249-252. (in Japanese)

Monteleone, L. \& McLellan, M. S. (1964): Epstein's pearls (Bohn's nodule) of the palate. J. Oral Surg., 22: $301-304$.

Moreillon, M. C. \& Schroeder, H. E. (1982): Numerical frequency of epithelial abnormalities, particularly microkeratocysts, in the developing human oral mucosa. Oral Surg., 53: 44-55.

Scott, J. H. (1955): The early development of oral cysts in man. Brit. Dent. J., 98: 109-114.

新生児の口腔粘膜囊胞についての臨床的観察

池村 邦男 ${ }^{1}$ 柿木 保明 ${ }^{2} \cdot$ 西尾 一方 ${ }^{2} \cdot$ 末永 義則 ${ }^{2}$

1産業医科大学雬科口腔外科 2産業医科大学皮膚科学教室

要 旨：日本人における新生児の口腔粘膜賈胞 (小結節) の発現頻度を調查した結果，54 1 例 中 $88.7 \%$ に認められた。この結果は欧米人や黒人のそれに比べて高い.また，囊胞の発 現は胎内での成長・発育に関連のあることが示唆された。これら囊胞（小結節）には種々

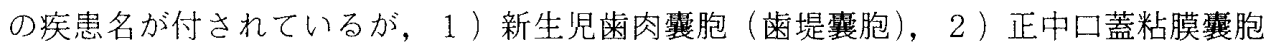
(Epstein 囊胞) の2つに分類すると簡明であると考える.

J. UOEH（産業医大誌）, 5 ( 2)：163-168 (1983) 